\title{
THE ROLE OF SELF-CONTROL IN COMMUNICATION BETWEEN THE MANAGERIAL STAFF AND EMPLOYEES IN EDUCATIONAL ORGANIZATIONS
}

\section{РОЛЬ САМОКОНТРОЛЮ В СПІЛКУВАННІ КЕРІВНИКІВ 3 ПЕРСОНАЛОМ ОСВІТНІХ ОРГАНІЗАЦІЙ}

\section{Snyadanko Iryna ${ }^{1}$}

DOI: http://dx.doi.org/10.30525/978-9934-571-27-5_50

\begin{abstract}
The subject of the research is focused on socio-psychological factors of self-control in communication between the managerial staff and the employees of educational establishments. The aim of the research is the analysis of psychological conditions of the development of self-control in communication between the managerial staff and the employees of educational organizations. At the core of the research of personality traits for self-control lays the cognitive-social approach by D. Kahneman, who emphasizes that self-control is a type of conscious cognitive activity. The approaches of cognitive psychologists were scrutinized (M. Csikszentmihalyi, S. Frederick, K. Stanovich, A. Kohn, W. Mischel etc.) regarding the understanding of mental activity process within the scope of the research in self-control of the personality.

The role of self-control as an important requirement in reaching goals by personality has been analyzed (Roy F. Baumeister etc.). At the same time, it is being stressed that efforts of will, or self-control, significantly wear out a person that reduces the desire for self-control after trying hard and pulling oneself together for a long time ('wearing out Ego' by Roy F. Baumeister). The level of personal self-control linked to motivational level (over-motivation $-\mathrm{R}$. Yerkes, J. Dodson). The situation where we can see a normal increase of the motivation usually improves the effectiveness of the activity, meanwhile the situation where excessive motivation is observed (over-motivation) usually leads to worsening of the outcome. The state of over-motivation can be built upon high level of anxiety, negative thoughts about
\end{abstract}

${ }^{1}$ Doctor of Psychology,

Associate Professor of Theoretical and Applied Psychology Department,

National University "Lviv Polytechnic", Ukraine 
the activity results, over-excitement of the nervous system, which can also influence the ability for self-control in personality. High anxiety level is, in turn, related to personality self-esteem (C. Spielberger).

The psycho-physiological factors of self-control formation were explained. The phenomenon of the psychological balance as a means for self-control conservation has been investigated. Interrelation between self-control and personal psychological maturity level has been explained. The main approaches to understanding the content of the personal psychological maturity were covered (B. Zeigarnik, S. Freud, A. Maslow, F. Perls, I. Yalom etc.), as a crucial requirement for self-control development in personality.

The psychological analysis of particularities of the educational administration was conducted, analyzing in particular the goals of educational organizations operation, roles and functions of management staff and employees of the organization (O. Bondarchuk, L. Karamushka, I. Snyadanko etc.).

The analysis of the notions 'communication' and 'interaction' were done. The aspects of managerial communication, main stages of the interaction were distinguished. The role of self-control in communication in managerial personnel of educational establishments was revealed. The factors improving self-control by means of communication, and managerial communication in particular, were explored. Self-control in communication affects the success in reaching the goals of personnel management in educational organizations. Special aspects of self-control in communication in managers linked with their managerial style.

According to the research results of self-control in communication between managers and employees of educational establishments, the following conclusions were drawn: self-control in communication plays an important role, because the ability for self-control in managers, managerial ability to control their thoughts, emotions, actions have a significant impact on level of reaching the goals and objectives in personnel management; managers' self-control level in communications related to his/her managerial style, in particular, low self-control level linked to prevalence of the position 'I am a child' (transactional analysis, E. Berne), which is commonly found in managers with liberal managerial style, meanwhile, high self-control level correlates with the position "I am an adult", excessively high self-control level is intrinsic to authoritarian style (position 'I am a parent'). 


\section{Snyadanko Iryna}

\section{1. Вступ}

Дослідження самоконтролю особистості є однією з актуальних проблем вивчення в когнітивній, когнітивно-поведінковій, організаційній, соціальній психології, психології управління людськими ресурсами тощо. Для керівників організації здатність до самоконтролю є важливим вмінням не лише для спілкування з іншими людьми, а також для самоорганізації власного життя, управління персоналом та організацією.

Метою даного дослідження $\epsilon$ аналіз соціально-психологічних умов формування самоконтролю в спілкуванні керівників 3 персоналом організації. Здатність до самоконтролю є однією з важливих характеристик особистості, формування якої починається в ранньому дитинстві і продовжується протягом всього життя. Психофізіологічні дослідження діяльності вищої нервової системи вказують, що за самоконтроль відповідає префронтальна ділянка головного мозку. Саме через те, що в дітей і підлітків префронтальні ділянки головного мозку не є достатньо сформованими, їх поведінка може бути імпульсивною, тобто характеризуватись низьким рівнем самоконтролю $[1 ; 2 ; 7 ; 12 ; 33]$.

\section{2. Когнітивний підхід}

Для розуміння механізму самоконтролю особистості розглянемо підхід когнітивних психологів щодо прийняття рішення та поведінки. К. Станович та Р. Вест [38] для розуміння процесу мислення та прийняття рішення особистості ввели терміни: «Система 1»- швидке, інтуїтивне мислення і «Система 2»- відповідає за повільне мислення та обчислення, що потребує зусиль. Слід розрізняти раціональність та інтелект. Щоб мислити послідовно і міркувати про щось серйозне, більшість з нас потребує самодисципліни, самоконтролю. Часте перемикання з одного завдання на інше та пришвидшення мисленнєвої діяльності - це неприємні види діяльності, які люди намагаються несвідомо уникати.

М. Ческентміхалій [31], у свою чергу, досліджував процес зосередження на роботі, яка не потребує зусиль та самоконтролю. Він запропонував називати такий процес - потоком, який описує, як непримусове зосередження, в якому втрачається відчуття часу, самих себе, своїх проблем, описують насолоду від цього стану та називає його 
«оптимальним досвідом». Потік розмежовує два види зусиль - зосередженість на якомусь завданні та навмисне контролювання уваги. У потоковому стані втримання уваги у виконанні різних видів діяльності не потребує додаткового самоконтролю. А це дозволяє вивільнити ще більше ресурсу для успішного виконання.

Д. Канеман [8] наголошує, що самоконтроль і мисленнєві зусилля є видами розумової діяльності. Дослідження показують, що люди, від яких вимагається одночасно виконувати складну розумову вправу та встояти проти якоїсь спокуси, більше схильні піддаватись спокусі, ніж ті, які не виконували розумові вправи. Коли «Система 2» зайнята, то «Система 1» сильніше впливає на ухвалення людиною рішень. Когнітивно зайняті люди, спілкуючись з іншою людиною, швидше зроблять егоїстичний вибір, ухвалять поверхове рішення. «Система 2» втрачає контроль над поведінкою, коли їй потрібно запам'ятовувати цифри, тобто мисленнєві навантаження послаблюють самоконтроль. Такий самий ефект має і алкоголь і фізичне виснаження.

Самоконтроль часто використовують, як синонім до сили волі. На думку багатьох вчених: секрет успіху особистості у житті полягає саме у самоконтролі, тому наголошують на необхідності тренувати силу волі. Експерименти Р. Баумайстера та його колег доводять, що всі види довільних зусиль, як когнітивних, емоційних так і фізичних, споживають енергію з спільного резерву. Досліджуваним пропонувалось виконувати завдання не одночасно, а послідовно. За результатами експерименту було зроблено висновок, що зусилля волі чи самоконтролю сильно втомлюють людину.

Якщо змушувати себе щось робити, то до наступного завдання бажання контролювати себе зменшується. Дане явище було названо - виснаження Его. Досліджувані, яким давали вказівку пригнічувати емоційну реакцію під час фільму, що викликає сильні почуття, погано проходили тест на фізичну витривалість. Коли учасників експерименту спочатку виснажували завданням харчуватись «здоровою» їжею та змушували опиратись спокусі з “̈̈сти шоколад, то такі учасники раніше за інших здавались під час виконання когнітивних завдань [23].

Д. Канеман наводить значний перелік ситуацій та завдань, які виснажують самоконтроль: не думати про білого ведмедя; ввічливо реагувати на нечемну поведінку партнера; прагнути справити враження на інших; робити вибір у ситуаціях, пов'язаних з конфліктними момен- 


\section{Snyadanko Iryna}

тами та ін. [8]. Застосування самоконтролю є неприємним і виснажливим завданням. Виснаження Его спричиняє часткову втрату мотивації. Застосувавши самоконтроль під час виконання одного завдання, ви застосовуєте його до іншого. Про вплив виснаження на формування суджень свідчить експеримент з ізраїльськими суддями. Результати експерименту свідчать, що стомлені і голодні люди схильні прийняти легше для них рішення [8].

Одна з головних функцій «Системи 2»-відстежувати і контролювати думки і дії, які їй «пропонує» «Система 1», дозволяти деяким 3 них позначитись на поведінці, а інші - пригнічувати або змінювати. Автоматична відповідь може бути інтуїтивною, привабливою, але хибною. Дослідження Д. Канемана та Ф. Шейна [8] про формування суджень, коли досліджуваним давали логічну задачку. Виявилось, що більшість досліджуваних давали хибну відповідь, адже користувались «Системою 2», яка схвалила інтуїтивну підказку, яку могла б спростувати. Люди, які відповідають інтуїтивно, не звертають увага на підказку загального плану, тобто не замислюються, для чого в питальник включили завдання з такою очевидною відповіддю.

Експеримент В. Мішеля [35], в якому чотирирічним дітям давали вибір: отримати одне печиво у будь-який момент, або отримати більшу винагороду (два печива), якщо вони зможуть зачекати 15 хвилин. Через 10-15 років між учасниками експерименту, які піддались та не піддались спокусі виявили суттєвий розрив. Ті учасники експерименту, які змогли чекати чверть години, тобто не піддались спокусі, виявили також більший самоконтроль під час виконання когнітивних завдань, вони легше переключали увагу, а у підлітковому віці з меншою вірогідністю вживали наркотики.

М. Мелія [14] наголошує на шкідливому впливі раннього самоконтролю та самодисципліни, який вимагається від сучасних дітей, батьки яких прагнуть бачити їх успішними. Вона наголошує на трьох основних правилах виховання сучасних дітей: як можна більше, як можна раніше, як можна краще. На думку батьків, не дотримання цих правил може призвести до ризику стати не успішним. Також батьки можуть використовувати дітей, щоб реалізувати свої мрії. На дітей покладаємо не дитячі завдання.

Під словом «самодисципліна» прийнято бачити панацею від самих різних проблем. Досягнення є результатом самоконтролю і самодисци- 
пліни. А. Кон [34] стверджує, що єдиний позитивний ефект самодисципліни у шкільному віці - високі оцінки. На думку А. Кона учні, які орієнтовані на оцінку, а не знання, менш зацікавлені в предметі та звикають мислити поверхнево. Висока ступень самоконтролю та орієнтація на зовнішні оцінки часто провокує тривогу та внутрішні конфлікти.

Одним із наслідків скеровування самодисципліни на успіх «породив» до такого синдрому сучасності, як синдром втрачених можливостей (Fear of missing out; скорочено FOMO). Це нав'язливий страх пропустити цікаву подію або хорошу можливість, яка також провокується соціальними сітями [36]. Результати дослідження вказують, що близько 50 \% людей мають цей синдром. В чоловіків синдром втрачених можливостей зустрічається частіше, ніж в жінок. Може виявлятись, як страх пропустити не лише цікаві події, новий досвід або матеріальну вигоду [37].

\section{3. Психологічна зрілість особистості та самоконтроль}

Дослідження взаємозв'язку домінуючого способу/системи мислення людини з рівнем іiї самоконтролю представляє лише один з підходів до розуміння їі механізмів цього явища. Важливу роль у формуванні самоконтролю відіграє психологічна зрілість особистості.

За Б. Зейгарник психологічна зрілість (протилежне явище вона називала - незрілість, інфантилізм) проявляється в здатності пристосовуватись до середовища згідно законів здорового глузду, готовністю виконувати земні завдання, розмежовує ідеальні та реальні цілі [7].

Ознаки психологічної зрілості за А. Маслоу [13], на думку якого найважливішою характеристикою психологічної зрілості є здатність особистості до самоактуалізації, також виділяв такі ознаки: сприйняття дійсності, незалежне від впливу власних потреб, стереотипів, установок; прийняття себе та інших такими, якими вони є, відсутність неприродніх форм поведінки; спонтанність проявів, простота і природність; ділова спрямованість, тобто зайнятість не собою, а своїми життєвим завданнями; позиція відстороненості по відношенню до більшості подій, що допомагає переносити неприємності і бути менш схильним до впливу ззовні; автономія і незалежність від оточення; стійкість від впливу зовнішніх факторів; демократичність у стосунках, готовність вчитися в інших; стійкі моральні норми; почуття гумору; креативність та ін. 


\section{Snyadanko Iryna}

Під поняттям психологічна зрілість інші дослідники розуміють здатність особистості підпорядковуватись більше принципу реальності (цей принцип забезпечує підпорядкованість отримання задоволення до певних вимог зовнішнього світу та об'єктивної дійсності), а не принципу задоволення (3. Фройд [26]). На думку 3. Фройда зріла особистість $є$ багатогранною, активною у вирішенні проблем, здатна прикладати зусилля, вміє працювати, вміє відкладати задоволення, відповідальна в взаємовідносинах з іншими людьми.

За В. Менделевичем, зріла особистість відповідальна та автономна у прийнятті рішень, не пред'являє претензії іншим у випадку невдач [15]. На думку Ф. Перлза зріла особистість це та, яка здатна до саморегуляції та опори на саму себе, а не інших людей, тобто вміє знаходити підтримку в самій собі [18]. За І. Яломом зріла особистість здатна усвідомлювати і приймати такі реалії, як смерть, самотність, свобода, безсенсовість життя, а також вміти переносити самотність, бути із своєю тривогою [16].

Психологічна зрілість особистості взаємопов'язана із рівнем її тривожності. Тривога, тривожні переживання є одними з базових переживань особистості. Слід розрізняти поняття тривога і тривожність. Тривога - емоційний стан очікування негативного розгортання подій, що виникає в ситуації, яка трактується, як загрозлива, небезпечна [15]. Тривожність розглядається, як психологічна особливість особистості переживати сильну тривогу з незначних приводів.

Поняття «тривога» ввів у психологію 3. Фройд, який розділив конкретний страх і несвідомий страх, тобто тривогу. I якщо страх є реакцією на конкретну загрозу, то тривога представляє собою дифузний, безпредметний, страх [26].

В клінічній психології, за Міжнародною класифікацією хворіб (МКХ10) [32], до симптомів тривоги відносять: побоювання / страх (турбота щодо майбутніх невдач, відчуття схвильованості, важко зосередитись та ін); моторне напруження (метушливість, головні болі, тремтіння, не може розслабитися); вегетативну гіперактивність (пітливість, тахікардія, епігастральній дискомфорт, запаморочення та ін. Якщо вищеперелічені симптоми спостерігаються кілька тижнів поспіль, то можна діагностувати тривожний розлад (тривожний невроз).

3. Фройд виділив такі види тривожності: реальний страх (тривожність через очікування загрози від зовнішнього світі); невротична 
тривожність (тривожність через невизначену небезпеку); моральна тривога (тривожність через сильне відчуття провини, сорому) [26].

Г. Прихожан виділяє різні види тривожності залежно від ситуації, наприклад, яка пов'язана з уявленням про себе - самооцінна тривожність, з спілкуванням - міжособистісна тривожність, тривожність через власну діяльність [19].

Ч. Спілбергер [22] виділяє два основних види тривожності: особистісна і ситуативна. Особистісна тривожність - являє собою базову рису особистості, що формується в ранньому дитинстві. Це готовність людини до переживання страху і хвилювань $з$ приводу широкого кола суб'єктивно значущих явищ. Високий рівень особистісної тривожності негативно впливає на формування особистості, адже впливає на iii рішення. Саме через високу тривожність можна уникати відповідальності за прийняття рішень, уникати контактів з іншими людьми, прагнути досягати успіху тощо. Домінують мотиви уникнення невдач, уникнення покарання та ін.

Ситуативна тривожність - це переживання, що виникають у конкретній ситуації, реакція на конкретні події. Ситуативна тривожність може проявлятись в різних ситуаціях: публічний виступ, спілкування 3 протилежною статтю, спілкування по телефону та ін. Ситуативна тривожність може перерости в особистісну, адже невпевненість через тривожність в одній сфері може переноситись, поширюватись на інші аспекти життєдіяльності особистості [22].

На рівень самоконтролю особистості негативний вплив мають тривожні думки, щодо виконання завдання, адже короткочасна пам“ять буде зайнята цими думками. Також на самоконтроль у діяльності негативно впливає і перемотивація. Закон Йєркса-Додсона доводить, що зростання мотивації спочатку підвищує рівень ефективності навчання/ діяльності, а потім настає зниження продуктивності. Існує певна межа, за якою подальше збільшення мотивації призводить до погіршення результатів. Щоб здійснювати діяльність, необхідна достатня мотивація. Однак, якщо мотивація занадто сильна, збільшується рівень активності та напруги, внаслідок чого в діяльності (і в поведінці) наступають певні розлади, тобто ефективність роботи погіршується. В такому випадку високий рівень мотивації викликає небажані емоційні реакції (напруга, хвилювання, стрес тощо), що призводить до погіршення діяльності [39]. 


\section{Snyadanko Iryna}

\section{4. Менеджер освітньої організації}

Проаналізуємо поняття освітня організація, освітня установа, заклад освіти та ін. Освітня установа - це установа, яка здійснює освітній процес, реалізуючи одну або декілька освітніх програм [6]. Під поняттям установа розуміємо орган, що виконує певні управлінські, культурно-освітні або соціально-побутові функції, це штат службовців 3 адміністрацією, що відає якою-небудь галуззю чи галузями народного господарства, торгівлі, культури, науки тощо, має самостійний кошторис або перебуває на державному бюджеті [20].

Заклад - це установа з певним штатом службовців і адміністрацією, що працюють в якій-небудь галузі освіти, науки, культури, медицини i т. ін. [20]. Поділяючи на галузі виокремлюють заклади освіти. Заклад освіти є установою, яка провадить освітню діяльність на основі програм затверджених МОН України для середньої, середньої професійної та професійної освіти, а також видає документи про освіту [6].

Згідно з Законом України «Про вищу освіту» вищий навчальний заклад представляє окрему установу, яка є юридичною особою приватного або публічного права. Вищий навчальний заклад діє згідно ліцензії на освітню діяльність, має здійснювати наукову, науково-технічну, інноваційну, методичну діяльність та ін. [6].

Під поняттям «організація» розуміють об’єднання людей і ресурсів, створене для виконання тих чи інших завдань, задоволення інтересів і потреб людей $[9 ; 10 ; 21]$.

У літературі зазначають, що поняття «організація» $є$ ширшим i включає у себе поняття «установа». Крім того, установи діють на некомерційній основі, а організація може бути і комерційною, і не комерційною [28]. Відповідно, до закладів вищої освіти доцільно застосовувати поняття «освітні організації», що розширює межі іiі функціонування, не лише як організації, яка надає освітні послуги, а ще і проводить комерційну діяльність.

Також слід розрізняти поняття «освітня організація», «організація, яка здійснює освітню діяльність», «організація, яка здійснює навчання». Організачія - створення певної структури, яка дає можливість членам колективу ефективно працювати для досягнення цілей, що стоять перед ним [9]. Освітня організація - це некомерційна організація, яка на підставі ліцензії здійснює освітню діяльність як основний вид діяльності відповідно до цілей, заради досягнення яких така організація створена [4]. 
Організаиія, яка здійснює освітню діяльність, - освітня організація, що здійснюють навчання. Організація, які здійснюють навчання, реалізує освітні програми, забезпечує виховання учнів [28].

Організачія, яка здійснює навчання, - юридична особа, яка на підставі ліцензії, разом з основною діяльністю здійснює освітню діяльність як додатковий вид діяльності [4].

Головною метою діяльності освітньої організації є забезпечення навчання, виховання і розвитку особистості. I саме на забезпечення цієї мети мають працювати всі рівні управління $[4 ; 21 ; 28]$.

Проаналізуємо поняття керівництво, менеджмент, керівник та менеджер освітньої організації. Під поняттям керівництво розуміємо здійснення впливу на людей та налагодження з ними міжособистісних стосунків з метою виконання завдань та цілей організації [9].

Корівника освітньої організації також можна називати менеджером освіти - професійний керівник освіти, який пройшов спеціальну підготовку з проблем управління [9].

Менеджмент освітніх організацій можна визначити як спеціальний вид діяльності в освітній організації, який несе відповідальність за досягнення поставлених цілей шляхом ефективного використання ресурсів [9].

Управлінська діяльність - це професійна діяльність у сфері «людина-людина» [42], що вимагає від суб'єкта діяльності відповідних умінь, зокрема: уміння налагоджувати і підтримувати ділові контакти, розуміння стану людини, впливу на інших, витримки, спокою, товариськості, комунікативних умінь [88; 134]. Оволодіння уміннями, необхідними для сфери «людина - людина», потребує комунікативних здібностей [179; 181].

Первинні функції управління об'єднуються між собою двома процесами: комунікацією (обмін інформацією) і прийняттям рішень (відбір альтернатив при здійсненні управлінських функцій). При цьому керівництво (лідерство) виступає як самостійна діяльність, яка передбачає можливість впливати на окремих працівників і групи працівників так, щоб вони працювали задля досягнення цілей, що дуже важливо для успіху організації [9].

Діяльність керівника освітньої організації, як будь-яка професійна діяльність представляє складну динамічну систему, до складу якої входять численні елементи, наприклад, Н. Кузьміна [11] виокремлює 


\section{Snyadanko Iryna}

такі: конструктивну (конструктивно-змістова, конструктивно-оперативна, конструктивно-матеріальна) або змістову (професійні спеціальні знання необхідні для здійснення певної професійної діяльності); організаторську або управлінську (ефективна організація, планування і реалізація власної професійної діяльності і, можливо, залежно від посади, діяльності інших людей); комунікативну (вміння спілкуватись iз колегами, 3 діловими партнерами, 3 підлеглими, з вищим керівництвом тощо для ефективної професійної діяльності).

Важливе значення для здійснення ефективної управлінської діяльності є формування в керівника психологічної компетентності. Згідно підходу Т. Щербакової [29], у структурі психологічної компетентності можна виокремити: 1) когнітивну компетентність, що забезпечує ефективне розв'язання проблем за рахунок розширення індивідуального паттерну оптимального пошуку рішень, тактичного та стратегічного навчання; 2) комунікативну компетентність, що дає можливість успішно позиціонувати себе як суб'єкта спілкування, продукуючи позитивні стосунки з іншими людьми; 3) соціальну компетентність, яка забезпечує адаптацію, можливість високих досягнень у результаті застосування конструктивних стратегій активності при збереженні адекватності поведінки в динамічній соціальній реальності; 4) автопсихологічну компетентність, що зумовлює ефективність прогресивного розвитку через активізацію особистісних ресурсів, саморефлексію на основі самодіагностики власних можливостей, оптимізацію саморегуляції та самоконтролю, а також індивідуальну систему способів і прийомів психологічної підтримки.

3 позиції формування психологічної компетентності управлінську діяльність можна представити, як складний процес, який забезпечується сукупністю кількох сфер управління: управління собою (самоуправління), управління своєю життєдіяльністю та управління іншими людьми /організацією [21].

Ефективність самоконтролю в спілкуванні керівників обумовлена вміннями управляти собою, тобто здійснювати самоуправління. На сьогодні, дослідження різних аспектів самоуправління є одними 3 актуальних в психології. Це дослідження: емоційної стійкості, стресостійкості, саморегуляції, самоефективності, самоконтролю, регулюваннні функціональних станів людини та ін. $[3 ; 4 ; 9 ; 21 ; 24 ; 25$; $33 ; 35]$. 


\section{5. Комунікація у освітній організації}

Проаналізуємо зміст, типи та функції комунікацій в освітній організації. Комунікації в освітніх організаціях представляють собою обмін інформацією між іiі членами, а управлінські комунікації це комунікації керівників організації. В організації можна виділити такі види комунікацій: між організацією і середовищем, міжрівневі, між різними відділами, між працівниками, між керівником і підлеглими, між керівником і робочою групою.

За Б. Ломовим [12], спілкування можна характеризувати за такими рівнями: макрорівень - спілкування представляє собою складну сітку взаємозв'язків індивіда з іншими людьми, соціальними групами та розглядається як важливий аспект образу життя людини; мезорівень - спілкування розглядається як сукупність цілеспрямованих, логічно завершених контактів або ситуацій взаємодії між людьми; мікрорівень - увага зосереджується на аналізі одиниць спілкування, як поведінкові акти.

За Г. Андрєєвою [1], структура спілкування складається 3 трьох взаємозв'язаних факторів: комунікативний (обмін інформацією між індивідами), інтерактивний (обмін між учасниками спілкування не лише інформацією, але і діями), перцептивний (процес сприйняття та пізнання учасниками спілкування один одного, встановлення взаєморозуміння).

А. Бодальов [2] виділяв: пізнавальний, емеційний та діяльнісний компоненти спілкування. Також спілкування можна розглядати як взаємозв 'язок змістового та формального аспектів (Б. Паригін [17]).

За особливостями спрямованості спілкування може мати інструментальну, спрямовану на виконання завдань, та особистісну, на задоволення особистісних потреб та бажань, спрямованість.

Б. Ломов виділяє такі функції в спілкуванні: інформаційно-комунікативну (обмін інформацією), регулятивно-комунікативну (регуляція поведінки та спільної діяльності), афективно-комунікативну (регуляція емоційної сфери особистості) [12].

Для виокремлення функцій, яке відіграє спілкування в організації можна виділити такі (на основі класифікації А. Деркача, Н. Кузьминої [5]): соціально-психологічного відображення - спілкування виникає як результат і як форма свідомого відображення партнерами особливостей перебігу взаємодії; регулятивна - в процесі спілкування здійс- 
нюється опосередкований або безпосередній вплив на членів групи з метою змінити або збереження на тому ж рівні їі поведінки; пізнавальна - в процесі систематичного спілкування відбувається члени групи оволодівають знаннями про себе, один про одного, вміннями та навичками; експресивна - емоційний стан та переживання групи; соціальний контроль та соціалізація.

\section{6. Самоконтроль у спілкуванні між управлінським персоналом та робітниками}

Вміння і навички спілкування є одними з важливих у діяльності керівника. Ефективне керівництво передбачає, в першу чергу, ефективне міжособистісне спілкування в організації. Під поняттям «спілкування» розуміємо такий процес взаємодії між людьми, групами людей, в якому відбувається обмін інформацією, результатами діяльності тощо.

Л. Карамушка [9] управлінські комунікації поділяє за такими критеріями: за спрямованістю (внутрішні, зовнішні); за управлінським статусом (горизонтальні, вертикальні); за змістом (формальні, неформальні), за засобами комунікації (безпосередні, опосередковані).

Для розуміння особливостей спілкування керівників освітньої організації, проаналізуємо, якими якостями має володіти суб‘єкт управлінської діяльності: моральні якості, здатність до відповідальної поведінки, яка є мірою усвідомлення особистістю своїх професійних обов'язків і добровільного їх наслідування; особистісні властивості суб'єкта управління (наприклад: тривожність, нейротизм та емоційна стійкість); комунікативні навички, які необхідні для роботи в сфері професії «людина-людина»; психологічна культура, яка є серед необхідних професійно важливих якостей $[3 ; 9 ; 21]$.

Для аналізу особливостей самоконтролю в спілкуванні керівників освітніх організацій розглянемо трансакційний підхід Е. Берна (від лат. transactio - звернення) - словесний чи безсловесний обмін між двома людьми, який утворюється з подразнення і реакції між певними станами «Я» [30]. Трансакції в спілкуванні аналізують на основі трьох станів «Я» (Е. Берн), що визначають іiі поведінку: Я-батько /мати; Я-дорослий; Я-дитина.

Стан «Я - батько/мати» поділяють на кілька: «Я-турботливий батько/мати», «Я - критичний батько/мати». У стані «Я-критичний 
батько/мати» особистість авторитарно вказує, що треба або не треба робити. Критичне «Я - батько/мати» орієнтоване на те, як має бути, а не на те, як $\epsilon$ насправді. Такі люди не допускають, що щось може бути недосконало зроблено, що люди можуть помилятись, говорити неправду та ін. Керівник, в якого домінує стан «Я - батько/мати» швидше намагається знайти винного, а не аналізувати проблему. Разом $з$ тим, стан «Я-батько/мати» дає можливість успішно орієнтуватись в стандартних ситуаціях, застосовуючи перевірені стереотипи поведінки, забезпечує ефективну поведінку в ситуаціях дефіциту часу $[16 ; 30]$.

Керівники, які мають домінуючий стан «Я - батько/мати» мають, 3 одного боку, високий рівень самоконтролю в спілкуванні, а з іншого боку можуть бути імпульсивними і нестримними. К. Мухортин [16] вказує, що позиція «Я-батько» є однією з самих розповсюджених серед керівників. Головні помилки в комунікаціях здійснюються саме 3 цієї позиції, адже інший співбесідник автоматично має зайняти або дитячу захисну або нападаючу позицію. Керівник з батьківською позицією характеризується гіпервідповідальністю, завищеною самооцінкою та почуттям власної значимості. Він ставить себе вище за інших. Керівники в батьківський позиції діляться на два типи:

- керівники, які повчають: заставляють співбесідника зайти в дитячу позицію, або проявляють агресію, коли не можуть прийняти думки інших;

- керівники, які сварять: за порушення можуть просто кричати, а підлеглий, у свою чергу, може мовчки вислухати, а потім іншим висловлювати своє незадоволення керівництвом. В таких ситуаціях ставлення підлеглих до керівника починає працювати в захисній позиції, а не на досягнення результатів діяльності.

Стан «Я-дитина» характеризується природніми імпульсами, дитячою поведінкою, але діти вміють пристосуватись й інтуїтивно вірно реагувати. Тому розрізняють три форми прояву дитячої позиції [27]:

- природня дитяча позичія, яка характеризується неконтрольованим проявом почуттів, бажань, разом $з$ тим властива життєлюбність та працьовитість;

- пристосовницька дитяча позиція, яка проявляється в прагненні бути непомітним і робити те, що очікують, пасивно терпить, страждає, сподіваючись, що все вирішиться без нього; 


\section{Snyadanko Iryna}

- маленький професор, коли особистість інтуїтивно усвідомлює те, що має робити, як «Я-дорослий» реалізовуючи свої бажання за допомогою винахідливості та хитрощів.

На думку К. Мухортина [16] керівник в позиції «Я-дитина» уникає відповідальності, не хоче бути винним, уникає загальноприйнятих думок, є егоїстичний, егоцентричний та не бажає розвиватись.

Разом 3 тим, можна не погодитись 3 думкою К. Мухортина, адже в природній дитячій позиції керівник може бути дуже творчим та працьовитим, але з цієї позиції йому може бути важко управляти іншими людьми. Для керівника в позиції «Я-дитина» більше властивий ліберальний стиль управління [16], який характеризується тим, що підлеглі мають свободу приймати власні рішення, самостійно контролювати свою роботу. Такий стиль передбачає мінімальну участь керівника в управлінні. 3 іншого боку керівник-ліберал характеризується безініціативністю, очікуванням вказівок від вищого керівництва, не бажання приймати на себе відповідальність за вирішення проблем та їх наслідки; не послідовний в діях, легко піддається впливу оточуючих, схильний поступатись обставинам та ін.

Разом $з$ тим, такий керівник може бути дуже обережним, через свою невпевненість, що також свідчить про високий самоконтроль над своїми емоціями. У стосунках з підлеглими може бути дуже ввічливим, добрим, прагнути надати допомогу, вислухати критику, але неспроможним реалізувати ідеї. Такому керівнику легше самому виконати роботу, ніж заставити ії зробити підлеглого [16;27].

Для стану «Я-дорослий» характерним є глибоке продумування дій, аналіз. Формується $3 \Pi^{\prime}$ яти років та розвиток триває все подальше життя. Стан орієнтований на перебування «тут і зараз», об‘єктивно оцінює та перевіряє інформацію, добре пристосовується, інтелігентний, розумний, критично переглядає усталені норми $[27 ; 30]$.

Доросла позиція є однією з самих сильних в спілкуванні, адже спрямована на конструктивні дії. Спілкування відбувається на рівних (дорослий - дорослий). У дорослій позиції відсутня образа, але є місце для злості та розчарування. Головне, що ця позиція дає можливість людині бути максимально відвертою по відношенню до себе та свого співбесідника [27].

Керівнику у позиції «Я-дорослий» властивий демократичний стиль управління, який характеризується: вмінням делегувати частину своїх 
обов"язків підлеглим; вмінням формувати команду враховуючи компетентності їі членів; регулювати конфлікти за допомогою переговорів; орієнтуватись на команду, на цілі та результати діяльності, на розвиток персоналу організації та ін. [16; 27].

Виділяють такі стилі демократичного керівництва: «консультативний» - керівник довіряє підлеглим, консультується з ними; домінує заохочення, а не покарання; підлеглі прагнуть підтримати свого керівника; «партисипативний» - керівник повністю довіряє своїм підлеглим, завжди їх вислуховує та заслуховує всі конструктивні пропозиції; підлеглі приймають участь в формуванні цілей та контролю за їх виконанням.

Оптимальний рівень самоконтролю в спілкуванні керівників, який дає можливість ефективно взаємодіяти та управляти персоналом освітньої організації забезпечується позицією «Я-дорослий». Доросла позиція в спілкуванні характеризується повагою до співбесідника. Для ефективного спілкування керівник немає залишати підлеглого на рівні дитини, а має «підняти» його до рівня дорослого. Керівник, часто несвідомо, вводить підлеглого в дитячу позицію, наприклад таким питанням: «Ти чому спізнився?»У відповідь на таке питання підлеглий буде виправдовуватись і тим самим вставати в дитячу позицію.

При оптимальному рівні самоконтролю в спілкуванні керівник може застосовувати принципи ефективного спілкування [16]:

- Принцип «бутерброда» полягає в тому, що негативну інформацію, яку керівник має донести підлеглому подають не одразу. Спочатку говорять позитивну інформацію, хвалять підлеглого за його сильні сторони, потім говорять негативну інформацію, але розмову закінчують позитивною для підлеглого інформацією. Керівник ніби обгортає негативну інформацію в позитивну;

- Повага в спілкуванні у дорослій позиції;

- Правило балансу. Якщо керівник перелічив десять негативних моментів, то має згадати і десять позитивних; конкретність і чіткість. Працівник має чітко розуміти, що саме він має змінити, переробити; говорити лише про те, що дійсно можна змінити. Того, що змінити вже неможливо згадувати, нагадувати некоректно;

Також оптимальний рівень самоконтролю в спілкуванні дає можливість керівнику застосовувати принципи активного слухання [16; 27; 30]: кивати головою, щоб показати, що уважно слухає; казати: «так», «угу», відповідно до змісту розмови; допомагає співбесіднику закін- 


\section{Snyadanko Iryna}

чити фразу, що свідчить про те, що він уважно слухає співрозмовника; задає уточнюючи питання навіть коли йому не дуже цікаво; підтримує зоровий контакт зі співбесідником; посмішка. Необхідно виробити вміння посміхатись при зустрічі зі співбесідником, потім навчитись приємно посміхнутись відповідаючи на питання співрозмовника та в кінці зустрічі. Необхідно контролювати повагу, активне слухання i посмішку, щоб досягти успіху у спілкуванні.

При проведенні зборів самоконтроль в спілкуванні керівник дає можливість [16; 21; 27]: Не критикувати на загал (можна дати оцінку, але не принижувати підлеглого перед всіма); обговорювати не особистість, а ії вчинки; добре підготуватись до зборів, дотримуватись чіткого плану і спокійно збирати необхідну інформацію; фіксувати нові думки та ідеї, які виникають під час обговорення та ін.

Оволодіння техніками самоконтролю в спілкуванні керівників сприятиме покращенню управління персоналом освітньої організації.

\section{7. Висновки}

За результатами проведеного дослідження можна зробити такі висновки: самоконтроль у спілкуванні відіграє важливу роль, адже вміння керівника контролювати себе, свої думки, емоції та дії має суттєвий вплив на рівень досягнення цілей та завдань в управлінні персоналом; рівень самоконтролю керівника у спілкуванні взаємопов'язаний з його стилем управління, а саме, низький рівень самоконтролю взаємопов'язаний із домінуванням позиції «Я-дитина», яка властива керівникам із ліберальним стилем управління, високий рівень самоконтролю відповідає позиції «Я - дорослий», надто високий самоконтроль властивий авторитарному стилю (позиція «Я - батько»).

Ефективне спілкування керівників в процесі управління освітньою організацією, зокрема персоналом організації забезпечується високим рівнем самоконтролю, разом $з$ тим, надто високий рівень самоконтролю негативно впливатиме на взаємодію керівника 3 персоналом освітньої організації.

\section{Список літератури:}

1. Андреева Г.М. Социальная психология / Галина Михайловна Андреева. - М.: Аспект Пресс, 2007. - 363 с.

2. Бодалев А.А. Личность и общение / Алексей Александрович Бодалев. М.: Международная педагогическая академия, 1995. - 328 с. 


\section{The role of self-control in communication between the managerial staff...}

3. Бондарчук O.I., Пінчук Н.I. Технологія психологічної підготовки керівників освітніх організацій до діяльності в умовах змін. Теорія та методика управління освітою: електронне наукове фахове видання. - Режим доступу: http://www.umo.edu.ua/elektronne-naukove-faxove-vidannya-qteoryata-metodika-upravlnnya-osvtoyuq.

4. Бочелюк В.Й. Психологія управління інноваційними процесами в закладах освіти: монографія / В.Й. Бочелюк, І.Ю. Антоненко. - Запоріжжя: КПУ, 2011. - 415 c.

5. Деркач А.А. Акмеология - наука о путях достижения вершин профессионализма / А.А. Деркач, Н.В. Кузьмина. - М.: РАУ, 1993. - 23 с.

6. Закон України «Про вищу освіту» [Електронний ресурс]. - Режим доступу: http://vnz.org.ua/zakonodavstvo/111-zakon-ukrayiny-pro-vyschu-osvitu

7. Зейгарник Б.В. Патопсихология / Блюма Вульфовна Зейгарник. - М.: Московский университет, 1986. - 287 с.

8. Канеман Д. (2017). Мислення швидке й повільне / Деніел Канеман. К.: Наш формат, 2017. - 480 с.

9. Карамушка Л.М. Психологія освітнього менеджменту: навч. посібник / Людмила Миколаївна. - К.: Либідь, 2004. - 466 с.

10. Карамушка Л.М. Психологія організаційної культури: Навчальний посібник / Л.М. Карамушка, I.І. Сняданко. - Київ-Львів: Край, 2010. - 212 с.

11. Кузьмина Н.В. Способности, одаренность, талант учителя / Нина Васильевна Кузьмина. - Л.: Знание. - Л.: Знание, 1985. - 32 с.

12. Ломов Б.Ф. Методологические и теоретические проблемы психологии [Електронний ресурс]. - Режим доступу: http://biblioclub.ru/index. php?page $=$ book $\&$ id $=39189$

13. Маслоу А.Г. Мотивация и личность / Абрахам Гарольд Маслоу. - СПб.: Евразия, 1999. - 478 с.

14. Мелия М. Наши бедные богатые дети / Мария Мелия. - М.: Альпина нон-фикшн, 2017. - 228 с.

15. Менделевич В.Д. Клиническая и медицинская психология: Учебное пособие / Владимир Давыдович Менделевич. - М.: МЕДпресс информ, 2008. $432 \mathrm{c}$.

16. Мухортин К. Доброе слово и револьвер менеджера / Константин Мухортин. - М.: Альпина Паблишер, 2013. - 260 с.

17. Парыгин Б.Д. Анатомия общения / Борис Дмитриевич Парыгин. СПб: Михайлова, 1999. - 301 с.

18. Перлз Ф. Гештальт-семинары / Фредерик Перлз. - М.: Институт Общегуманитарных исследований, 2010. - 336 с.

19. Прихожан А.М. Психология тривожности / Анна Михайловна Прихожан. - СПб.: Питер, 2007. - 192 с.

20. Смоляр Л.Г., Котенко О.А. Мережеві структури як сучасна форма організації економічної діяльності [Електронний ресурс]. - Режим доступу: http://www.economy.nayka.com.ua/?op=1\&z=1660

21. Сняданко I.I. Психологія підготовки студентів технічних університетів до майбутньої професійно-управлінської діяльності: монографія / Ірина Ігорівна Сняданко. - Львів: ФОП Бадікова Н.О., 2016. - 462 с. 


\section{Snyadanko Iryna}

22. Спилбергер Ч. Концептуальные и методологические проблемы исследования тревоги / Чарльз Спилбергер // Стресс и тревога в спорте: междунар. сб. науч. ст. - Москва : Физкультура и спорт, 1983. - С. 12-24.

23. Тирни Дж. Сила воли. Возьми свою жизнь под контроль / Джон Тирни, Рой Баумейстер. - М.: ЭКСМО, 2017. - 304 с.

24. Тревога и тревожность: хрестоматия / Сост. и общая редакция В. М. Астапова. - М.: ПЕР СЭ, 2008. - 239 с.

25. Трейси Б. Нет оправданий. Сила самодисциплины / Брайан Трейси. ООО: Попурри, 2014. - 128 с.

26. Фройд 3. Вступ до психоаналізу / Зігмунд Фройд. - К.: Основи, 1998. $709 \mathrm{c}$.

27. Хміль Ф.І. Ділове спілкування / Федір Іванович Хміль. - Київ: Академвидав, 2004. - 280 с.

28. Что скрывается за новым термином «образовательная организация», чем этот термин отличается от термина «образовательное учреждение»? [Електронний ресурс]. - Режим доступу: http://xn--273--84d1f. xn--p1ai/voprosy_i_otvety/chto-skryvaetsya-za-novym-terminom-obrazovatelnayaorganizaciya-chem-etot-termin

29. Щербакова Т.Н. Психологическая компетентность учителя: акмеологический анализ: дисс. ...докт. псих. наук: 19.00.13 / Щербакова Татьяна Николаевна. - Ростов-на-Дону, 2006. - 470 с.

30. Berne E. Games People Play: The Psychology of Human Relationships / Eric Berne. - Grove Press, 1964. - 81p.

31. Csikszentmihalyi M. Flow: The Psychology of Optimal Experience / Mihaly Csikszentmihalyi. - New York: Harper and Row, 1990. - 298 p.

32. ICD-10 Version: 2010 [Electronic resources] - Retrieved from: http://apps.who.int/classifications/icd10/browse/2010/en\#/F41.1

33. Frederick S. Cognitive Reflection and Decision Making / Shane Frederick // Journal of Economic Perspectives. 19 (4), 2005. - P. 25-42.

34. Kohn A. Punished by Rewards. The Trouble with Gold Stars, Incentive Plans, A's, Praise, and Other Bribes / Alfie Kohn. - Houghton Mifflin Harcourt, 1999. -448 p.

35. Mischel W. Toward a cognitive social learning reconceptualization of personality. / Walter Mischel // Psychological Review, 80 (4). - 1973. - P. 252-283.

36. Przybylski A. Motivational, emotional, and behavioral correlates of fear of missing out / A. Przybylski, K. Murayama, C. De Haan, C. Gladwell // Computers in Human Behavior. 29 (4), 2013. - P. 1841-1848.

37. Riordan B. Fear of missing out (FoMO): the relationship between FoMO, alcohol use, and alcohol-related consequences in college students / B. Riordan, J. Flett, J. Hunter, D. Scarf, T. Conner // Annals of Neuroscience and Psychology [Electronic resources] - Retrieved from http://www.vipoa.org/neuropsychol/2/7

38. Stanovich K. What Intelligence Tests Miss: The Psychology of Rational Thought / Keith E. Stanovich // Yale University Press, 2010. - 328 p.

39. Yerkes, R. The relation of strength of stimulus to rapidity of habitformation / R. Yerkes, J. Dodson // Journal Comp. Neurol. Psychol. № 18. 1908. - P. 459-482. 


\section{The role of self-control in communication between the managerial staff...}

\section{References:}

1. Andreeva, G. M. (2001). Sotsialnaya psihologiya [Social Psychology]. M.: Aspekt Press, 363 p. (in Russian).

2. Bodalev, A. A. (1995). Lichnost $i$ obschenie [Personality and communication]. M.: Mezhdunarodnaya pedagogicheskaya akademiya, 328 p. (in Russian).

3. Bondarchuk, O. I., \& Pinchuk N. I. (2014). Tekhnolohiia psykholohichnoi pidhotovky kerivnykiv osvitnikh orhanizatsii do diialnosti $v$ umovakh zmin. Teoriia ta metodyka upravlinnia osvitoiu: elektronne naukove fakhove vydannia [Technology of psychological training of heads of educational organizations to work in conditions of changes. Theory and methodology of education management: an electronic scientific professional edition]. Rezhym dostupu: http://www.umo.edu.ua/elektronne-naukove-faxove-vidannya-qteorya-ta-metodika-upravlnnya-osvtoyuq. (in Ukrainian).

4. Bocheliuk, V. Y., \& Antonenko, I. Yu. (2011). Psykholohiia upravlinnia innovatsiinymy protsesamy $v$ zakladakh osvity: monohrafia [Psychology of management of innovative processes in educational institutions: monograph] Zaporizhzhia: KPU, 415 p. (in Ukrainian).

5. Derkach, A.A., \& Kuzmyna, N.V. (1993). Akmeolohyia - nauka o putiakh dostyzhenyia vershyn professyonalyzma [Acmeology is a science of ways to achieve the peaks of professionalism]. - M.: RAU, 23 p. (in Russian).

6. Zakon Ukrainy "Pro vyshchu osvitu" [Law of Ukraine "On Higher Education"]. Elektronnyi resurs. Rezhym dostupu http://vnz.org.ua/zakonodavstvo/111-zakon-ukrayiny-pro-vyschu-osvitu

7. Zeiharnyk, B.V. (1986). Patopsykholohyia [Pathopsychology]. M.: Moskovskyi unyversytet, 287 p. (in Russian).

8. Kaneman, D. (2017). Myslennia shvydke y povilne [Thinking, fast and slow]. K.: Nash format, 480 p. (in Ukrainian).

9. Karamushka, L. M. (2004). Psykholohiia osvitnoho menedzhmentu: navch. Posibnyk [Psychology of Educational Management]. K.: Lybid, 466 p. (in Ukrainian).

10. Karamushka, L.M. \& Sniadanko, I.I. (2010). Psykholohiia orhanizatsiinoi kultury [Psychology of organizational culture]: Navchalnyi posibnyk. Kyiv-Lviv: Krai, 212 p. (in Ukrainian).

11. Kuzmina, N. V. (1985). Sposobnosti, odarennost, talant uchitelya [Abilities, giftedness, talent of the teacher]. L.: Znanie, 32 p. (in Russian).

12. Lomov, B.F. (2008). Metodologicheskie i teoreticheskie problemyi psihologii [Methodological and theoretical problems of psychology]. Moskva: DirektMedia. Rezhim dostupu http://biblioclub.ru/index.php?page=book\&id=39189 (in Russian).

13. Maslou, A. G. (1999). Motivatsiya i lichnost [Motivation and Personality]. $\mathrm{SPb} .:$ Evraziya, 478 p. (in Russian).

14. Meliya, M. (2017). Nashi bednyie bogatyie deti [Our poor, rich children] M.: Alpina non-fikshn. (in Russian).

15. Mendelevich, V. D. (2008). Klinicheskaya i meditsinskaya psihologiya [Clinical and medical psychology]: Uchebnoe posobie. M.: MEDpress inform, 432 p. (in Russian). 


\section{Snyadanko Iryna}

16. Muhortin, K. (2013). Dobroe slovo i revolver menedzhera [Kind word and manager revolver]. M.: Alpina Pablisher, 260 p. (in Russian).

17. Paryigin, B. D. (1999). Anatomiya obscheniya [Anatomy of communication]. SPb: Mihaylova, 301 p. (in Russian).

18. Perlz, F. (2007). Geshtalt-seminaryi [Gestalt workshops]. Perevod s angl. M.: Institut Obschegumanitarnyih issledovaniy, 336 p. (in Russian).

19. Prihozhan, A. M. (2007). Psihologiya trivozhnosti [Psychology of Triviality] $\mathrm{SPb}$.: Piter, 191 p. (in Russian).

20. Smoliar, L. H. \& Kotenko, O. A. Merezhevi struktury yak suchasna forma orhanizatsii ekonomichnoi diialnosti [Network structures as a modern form of organization of economic activity]. Elektronnyi resurs. Rezhym dostupu http://www.economy.nayka.com.ua/?op=1\&z=1660 (in Ukrainian).

21. Sniadanko, I.I. (2016). Psykholohiia pidhotovky studentiv tekhnichnykh universytetiv do maibutnoi profesiino-upravlinskoi diialnosti [Psychology of the training of students of technical universities for future professional-management activities]: monohrafiia. Lviv: FOP Badikova N.O., 462 p. (in Ukrainian).

22. Spilberger, Ch. D. (1983). Kontseptualnyie i metodologicheskie problemyi issledovaniya trivogi [Conceptual and methodological problems of the study of anxiety]. Stres i trivoga v sporte: mezhdunar. zb. nauch. st. M.: Fizkultura i sport, pp. 12-24. (in Russian).

23. Tirni, Dzh., \& Baumeyster, R. (2017). Sila voli. Vozmi svoyu zhizn pod kontrol [Strength of will. Take your life under control]. M.: EKSMO, 304 p. (in Russian).

24. Trevoga i trevozhnost [Strength of will. Take your life under control]: hrestomatiya. (2008). M.: PERSE, 239 p. (in Russian).

25. Treysi, B. (2014). Net opravdaniy. Sila samodistsiplinyi [No Excuses. The Power of Self-Discipline]. OOO: Popurri, 128 p. (in Russian).

26. Froid, Z. (1998). Vstup do psykhoanalizu [Introduction to psychoanalysis]. Per. z nim. P. Tarashchuk. K.: Osnovy, 709 p. (in Ukrainian).

27. Khmil, F.I. (2004). Dilove spilkuvannia [Business communication]. Kyiv: Akademvydav, 280 p. (in Ukrainian).

28. Chto skryivaetsya za novyim terminom "obrazovatelnaya organizatsiya", chem etot termin otlichaetsya ot termina "obrazovatelnoe uchrezhdenie"? [What lies behind the new term "educational organization", than this term differs from the term “educational institution"?] Elektronniy resurs. Rezhim dostupu http://xn--273-84d1f.xn--p1ai/voprosy_i_otvety/chto-skryvaetsya-za-novym-terminom-obrazovatelnaya-organizaciya-chem-etot-termin (in Russian).

29. Scherbakova, T. N. (2010). Psihologicheskaya kompetentnost uchitelya: akmeologicheskiy analiz [Psychological competence of the teacher: akmeological analysis]: monografiya. R-na-Donu, 470 p. (in Russian).

30. Berne, E. (1964). Games People Play: The Psychology of Human Relationships. Grove Press, 81 p.

31. Csikszentmihalyi, M. (1990). Flow: The Psychology of Optimal Experience. New York: Harper and Row, 298 p.

32. ICD-10 Version: 2010. Electronic resources. Retrieved from http://apps. who.int/classifications/icd10/browse/2010/en\#/F41.1 


\section{The role of self-control in communication between the managerial staff...}

33. Frederick, S. (2005). Cognitive Reflection and Decision Making /. Journal of Economic Perspectives. 19 (4), pp. 25-42.

34. Kohn, A. (1999). Punished by Rewards. The Trouble with Gold Stars, Incentive Plans, A's, Praise, and Other Bribes. Houghton Mifflin Harcourt, 448 p.

35. Mischel, W. (1973). Toward a cognitive social learning reconceptualization of personality. Psychological Review. 80, pp. 252-283.

36. Przybylski, A. \& Murayama, K., \& De Haan, C., \& Gladwell, V. (2013). Motivational, emotional, and behavioral correlates of fear of missing out. Computers in Human Behavior. 29 (4), pp. 1841-1848.

37. Riordan, B., \& Flett, J., \& Hunter, J., \& Scarf, D. \& Conner, T. (2015) Fear of missing out (FoMO): the relationship between FoMO, alcohol use, and alcohol-related consequences in college students. Annals of Neuroscience and Psychology. Electronic resources. Retrieved from http://www.vipoa.org/neuropsychol/2/7

38. Stanovich, K. (2010). What Intelligence Tests Miss: The Psychology of Rational Thought. Yale University Press, 328 p.

39. Yerkes, R., Dodson, J. (1908). The relation of strength of stimulus to rapidity of habit-formation. Journal Comp. Neurol. Psychol. 18, pp. 459-482. 